\title{
SISTEM KLASIFIKASI DAN PENCARIAN JURNAL DENGAN MENGGUNAKAN METODE NAÏVE BAYES DAN VECTOR SPACE MODEL
}

\author{
Amalia Indranandita ${ }^{(1)}$, Budi Susanto ${ }^{(2)}$, Antonius Rachmat $C^{(3)}$
}

\begin{abstract}
Abstrak:
Kebutuhan konsumen terhadap informasi dalam bentuk jurnal atau artikel ilmiah semakin meningkat, sehingga pengelompokan jurnal dibutuhkan untuk mempermudah pencarian informasi. Topik jurnal diharapkan dapat mewakili isi jurnal, tanpa harus membaca secara keseluruhan. Dalam kenyataannya, pengelompokan jurnal yang mengacu topik/kategori tertentu sulit dilakukan jika hanya mengandalkan query biasa.

Sistem klasifikasi dan pencarian jurnal dengan metode Naïve Bayes dan Vector Space Model dengan pendekatan Cosine diharapkan membantu pengguna dalam penentuan topik/kategori dan menghasilkan daftar jurnal berdasarkan urutan tingkat kemiripan. Proses text mining dilakukan untuk mempersiapkan kebutuhan dasar sistem. Tahapan proses text mining adalah text preprocessing dengan parsing, text transformation dengan stemming dan stopwords removal, feature selection dan pattern discovery.

Klasifikasi NaÏve Bayes menghasilkan prediksi baik jika vektor yang terbentuk mewakili setiap kategori. Sedangkan pencarian Vector Space Model dengan pendekatan Cosine menghasilkan recall sebesar $54.8 \%$ dan precision sebesar $60.7 \%$. Oleh karena itu, dibangun sistem klasifikasi dan pencarian yang dapat membantu pengguna, karena dilengkapi pencarian detil dengan pengetahuan label kategori hasil klasifikasi dan fitur metadata.
\end{abstract}

\section{Kata Kunci : Text Mining, Naïve Bayes, Vector Space Model}

\section{Pendahuluan}

Kebutuhan konsumen terhadap informasi dalam bentuk jurnal atau artikel ilmiah semakin meningkat, sehingga pengelompokan jurnal dibutuhkan untuk mempermudah pencarian informasi. Informasi penting dari jurnal berupa topik (kategori) yang menggambarkan pokok pembahasan secara umum. Pemberian label topik diharapkan membantu konsumen dalam memahami isi jurnal, tanpa harus membaca secara keseluruhan. Dalam kenyataannya, pengelompokan jurnal yang mengacu topik/kategori tertentu sulit dilakukan jika hanya mengandalkan query biasa. Query adalah standard query language untuk mendefinisikan dan memanipulasi database yang didukung oleh database server.

Pemilihan query yang kurang spesifik akan menghasilkan pencarian yang tidak relevan. Hasil jurnal pada peringkat awal belum tentu relevan, sehingga dapat dinyatakan pencarian dengan query biasa tidaklah efektif. Jadi, dibutuhkan pengelompokan jurnal untuk mengatasi kendala tersebut. Permasalahan yang muncul adalah bagaimana sistem dapat melakukan pengelompokan dan pencarian jurnal yang relevan untuk memenuhi kebutuhan konsumen?

Oleh karena itu, akan dirancang sistem klasifikasi dan pencarian jurnal dengan menggunakan metode Naïve Bayes dan Vector Space Model. Diharapkan dengan dukungan dari dua metode tersebut, sistem dapat membantu pengguna dalam melakukan penentuan topik/kategori dan menghasilkan jurnal-jurnal yang sama/mirip berdasarkan tingkat kesamaan.

Berikut adalah beberapa batasan masalah dari sistem yang dibuat. Artikel ilmiah dalam bentuk jurnal berbahasa Inggris yang bersumber pada http://www.proquest.com/pqdweb. Jurnal diklasifikasikan dalam 5 kategori, yaitu Health, Music, Politics, Sport dan Technology. Atribut data

\footnotetext{
(1) Amalia Indranandita, Mahasiswa Teknik Informatika, Fakultas Teknik, Universitas Kristen Duta Wacana

3) Budi Susanto, S.Kom., M.T., Dosen Teknik Informatika, Fakultas Teknik, Universitas Kristen Duta Wacana

Antonius Rachmat C, S.Kom, M.Cs., Dosen Teknik Informatika, Fakultas Teknik, Universitas Kristen Duta Wacana
} 
pelatihan berupa kategori, judul, isi abstrak dan keywords dari jurnal. Atribut metadata hasil pencarian berupa kategori, tanggal dan penulis dari jurnal. Proses transformasi teks menggunakan metode Porter Stemmer dan penghapusan stopwords. Pembobotan token menggunakan algoritma TF-IDF disertai dengan normalisasi, dimana perhitungan TF untuk atribut judul dan keywords dikalikan dengan nilai 10. Bentuk masukan sistem berupa file jurnal berformat .htm yang bersumber Proquest. Bentuk keluaran sistem adalah label berupa topik/kategori berdasarkan hasil klasifikasi disertai jurnal-jurnal yang telah di-ranking berdasarkan tingkat kesamaan dalam pencarian. Sistem dibangun dalam bentuk aplikasi web yang diuji pada jaringan lokal.

\section{Landasan Teori}

\section{$2.1 \quad$ Text Mining}

Menurut Feldman, R. dan Sanger, J., "text mining adalah sebuah proses pengetahuan intensif dimana pengguna berinteraksi dan bekerja dengan sekumpulan dokumen dengan menggunakan beberapa alat analisis" (2007, hlm. 1). Text mining mencoba untuk mengekstrak informasi yang berguna dari sumber data melalui identifikasi dan eksplorasi dari suatu pola menarik. Sumber data berupa sekumpulan dokumen dan pola menarik yang tidak ditemukan dalam bentuk database record, tetapi dalam data teks yang tidak terstruktur.

Tahapan proses text mining dibagi menjadi 4 tahap utama, seperti pada Gambar 1. Masukan awal dari proses adalah berupa suatu data teks dan akan menghasilkan keluaran berupa pola sebagai hasil tafsiran.

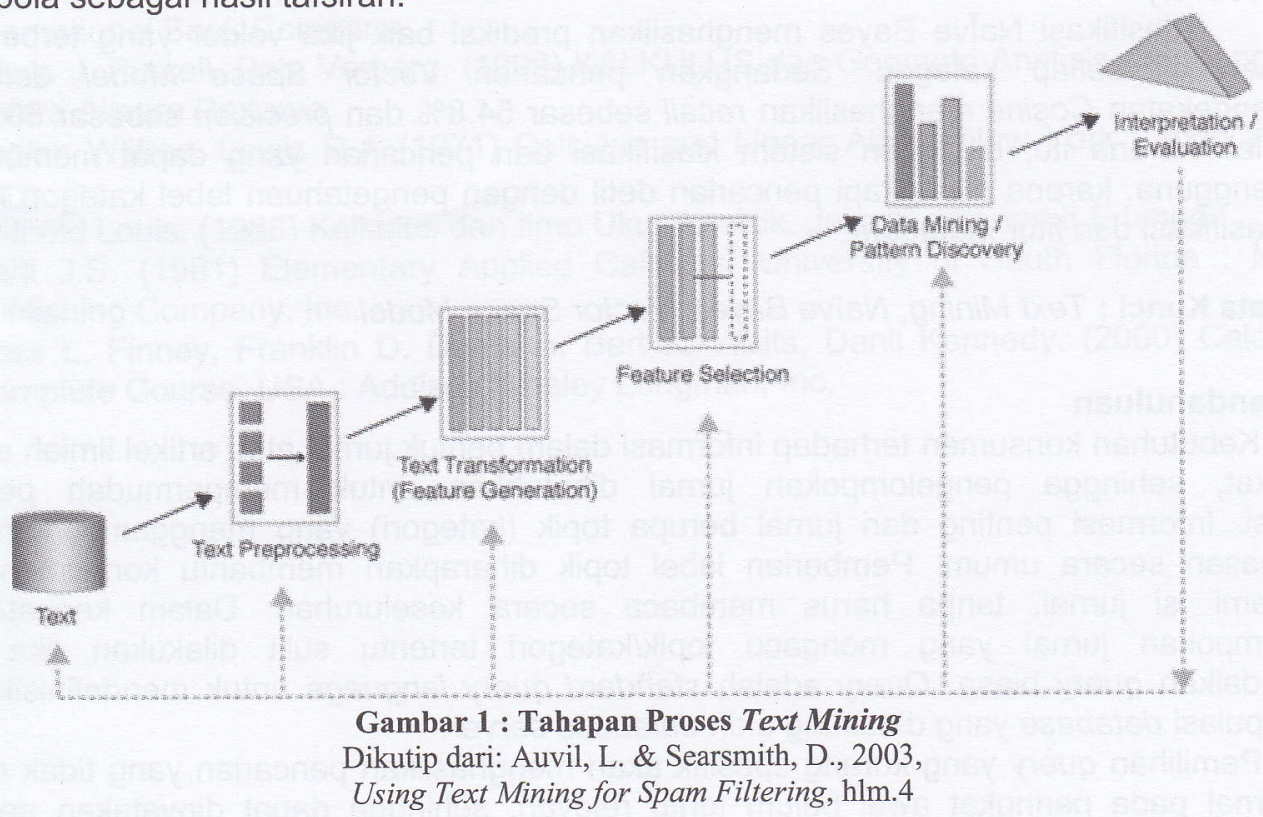

\subsection{Text Preprocessing}

Tahap proses awal terhadap teks untuk mempersiapkan teks menjadi data yang akan diolah lebih lanjut. Sekumpulan karakter yang bersambungan (teks) harus dipecah-pecah menjadi unsur yang lebih berarti. Hal ini dapat dilakukan dalam beberapa tingkatan yang berbeda. Suatu dokumen dapat dipecah menjadi bab, sub-bab, paragraf, kalimat, kata dan bahkan suku kata atau fonem. Parsing/tokenizing adalah proses memecah teks menjadi kalimat dan kata/token (Feldman, R. \& Sanger, J., 2007, hlm. 60). Fitur ini terdiri dari tipe kapitálisasi, keberadaan digit, tanda baca, karakter spesial dan lain sebagainya. Hasil keluaran dari proses tokenizing akan dipergunakan sebagai masukan dalam tahap transformasi teks.

\subsection{Text Transformation}

Tahapan yang dipergunakan untuk mengubah kata-kata ke dalam bentuk dasar, sekaligus untuk mengurangi jumlah kata-kata tersebut. Pendekatan yang dapat dilakukan yaitu dengan stemming dan penghapusan stopwords. 
Teknik untuk meningkatkan performa, yaitu dengan cara menemukan variasi token dari token pencarian yang dimasukkan. Stemming dapat dilakukan pada saat indexing atau pencarian (Frakes, W. B. \& Baeza, R., 1992, hlm. 131). Keuntungan stemming saat indexing adalah efisiensi dan kompresi file.

Stoplist berisi kumpulan kata yang 'tidak relevan', tetapi seringkali muncul dalam sebuah dokumen. Dengan kata lain, stoplist berisi sekumpulan stopwords (Han, J. \& Kamber, M., 2001, hlm. 430). Stopwords removal adalah proses menghilangkan kata yang 'tidak relevan' dari sebuah dokumen teks dengan cara membandingkannya dengan stoplist yang ada.

\subsection{Feature Selection}

Walaupun teks sudah melalui tahapan transformasi teks, tetapi tidak semua kata yang tersisa menggambarkan isi dari dokumen. Tahap seleksi fitur (feature selection) bertujuan mengurangi dimensi dari suatu kumpulan teks. Dengan kata lain, menghapus kata-kata yang dianggap tidak penting atau tidak menggambarkan isi dokumen berdasarkan frekuensi kemunculan kata tersebut.

\subsection{Pattern Discovery}

Tahapan penemuan pola adalah tahap terpenting dari keseluruhan proses text mining. Merupakan penemuan pola atau pengetahuan dari keseluruhan teks.

\subsection{Information Retrieval}

Menurut Han, J. dan Kamber, M., information retrieval (IR) adalah pengorganisasian dan penemuan informasi dari sejumlah besar dokumen berbasis teks (2001, hlm. 428). Information retrieval merupakan bidang yang berkembang secara paralel dengan sistem basis data selama beberapa tahun. Sistem basis data lebih fokus pada query dan proses transaksional dari struktur data. Sedangkan dalam sistem information retrieval ditemukan dokumen yang tidak terstruktur, pencarian berdasarkan kata kunci dan tingkat kesamaan.

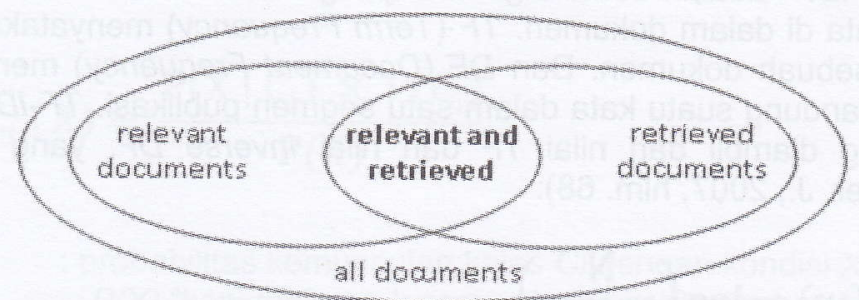

Gambar 2 : Hubungan antara Dokumen Relevant dan Retrieved Dikutip dari: Han, J. \& Kamber, M., 2001,

Data Mining: Concepts and Techniques, hlm.429

2 dasar pengukuran untuk mengukur kualitas dari penemuan teks, yaitu:

- Precision: tingkat ketepatan hasil klasifikasi terhadap suatu kejadian.

$$
\text { precision }=\frac{\mid\{\text { Relevant }\} \cap\{\text { Retrieved }\} \mid}{\mid \text { (Retrieved }\} \mid}
$$

Keterangan:

precision

$\{$ Relevant\}

\{Retrieved\}

: tingkat ketepatan

: kumpulan dokumen yang relevan

: kumpulan dokumen yang ditemukan

- Recall: tingkat keberhasilan mengenali suatu kejadian dari seluruh kejadian yang seharusnya dikenali.

$$
\text { recall }=\frac{\mid[\text { Relevant }\} \cap\{\text { Retrieved }\} \mid}{\mid\{\text { Relevant }] \mid}
$$




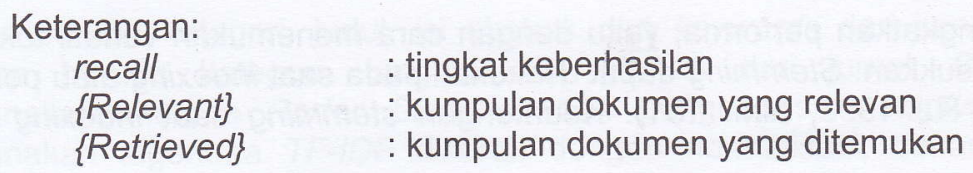

Dalam serangkaian percobaan untuk mengukur performa dari suatu metode/algoritma, digunakan query yang tidak hanya satu dan dari setiap hasil kemudian dirata-rata untuk setiap level recall-nya. Berikut adalah persamaan untuk menghitung rata-rata pada setiap level recall.

$$
\bar{p}(r)=\sum_{i=1}^{N_{q}} \frac{P_{1}(r)}{N_{q}}
$$

dimana $P(r)$ adalah rata-rata precision pada level recall yang ke-r, $N q$ adalah jumlah query yang digunakan, dan $\mathrm{Pi}(r)$ adalah nilai precision pada level recall ke-r untuk query yang ke-i.

Dikarenakan level recall dari setiap query mungkin berbeda dari standar 11 level recall, maka diperlukan sebuah prosedur interpolasi. Prosedur tersebut adalah sebagai berikut, jika $r j, j$ $\epsilon\{0,1,2, \ldots, 10\}$, mereferensikan level recall standar yang ke-i, maka:

$$
\overline{\mathrm{P}}\left(\mathrm{r}_{\mathrm{j}}\right)=\max _{\mathrm{rj}} \leq \mathrm{r} \leq \mathrm{r}_{\mathrm{H}+2} \mathrm{P}(\mathrm{r})
$$

yang berarti precision interpolasi yang ke-j pada level recall yang standar adalah precision maksimum dari semua level recall diantara level recall yang ke-j sampai yang ke- $(j+1)$.

\subsection{Algoritma TF-IDF (Term Frequency Inverse Document Frequency)}

Algoritma TF-IDF adalah suatu algoritma yang berdasarkan nilai statistik menunjukkan kemunculan suatu kata di dalam dokumen. TF (Term Frequency) menyatakan banyaknya suatu kata muncul dalam sebuah dokumen. Dan DF (Document Frequency) menyatakan banyaknya dokumen yang mengandung suatu kata dalam satu segmen publikasi. TF-IDF adalah nilai bobot dari suatu kata yang diambil dari nilai TF dan nilai inverse $D F$, yang didefinikan dengan (Feldman, R. \& Sanger, J., 2007, hlm. 68):

$$
\begin{aligned}
& \operatorname{IDF}(w)=\log \left(\frac{N}{D F(w)}\right) \\
& \operatorname{TF}-\operatorname{IDF}(w, d)=\operatorname{TF}(w, d) \times \operatorname{IDF}(w)
\end{aligned}
$$

Keterangan:

$\begin{array}{ll}T F-I D F(w, d) & : \text { bobot suatu kata dalam keseluruhan dokumen } \\ w & : \text { suatu kata (word) } \\ d & : \text { suatu dokumen (document) } \\ T F(w, d) & : \text { frekuensi kemunculan sebuah kata } w \text { dalam dokumen } d \\ I D F(w) & : \text { inverse } D F \text { dari kata } w \\ N & : \text { jumlah keseluruhan dokumen } \\ D F(w) & : \text { jumlah dokumen yang mengandung kata } w\end{array}$

\subsection{TF-IDF Normalization}

Berdasarkan rumus [6] di atas, berapapun besarnya nilai $\operatorname{TF}(w, d)$, apabila nilai $N=$ $D F(W)$ maka akan didapatkan hasil 0 (nol) untuk perhitungan IDF. Untuk itu, dapat ditambahkan nilai 1 pada sisi IDF, sehingga perhitungan $T F(w, d)$ menjadi sebagai berikut: 


$$
\operatorname{TF}-\operatorname{IDF}(w, d)=\operatorname{TF}(w, d) \times\left(\log \left(\frac{N}{D F(w)}\right)+1\right)
$$

Rumus [7] dinormalisasi dengan rumus [8] dengan tujuan untuk menstandarisasi nilai $T F(w, d)$ ke dalam interval 0 sampai 1. Rumus TF-IDF dengan menggunakan normalisasi (Intan, R. \& Defeng, A., 2006, hlm. 3) adalah:

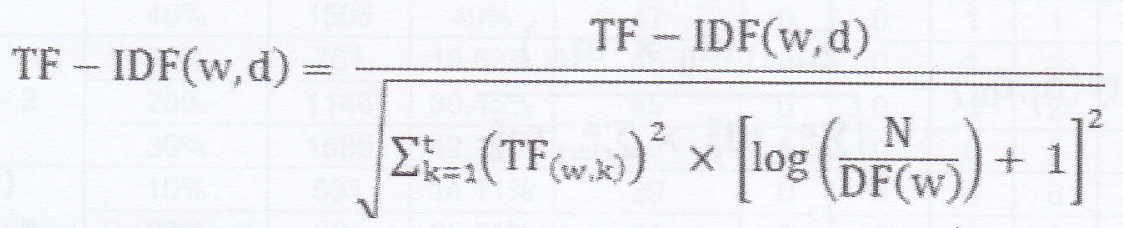

Keterangan tambahan:

$$
\begin{aligned}
& \text { TF }(w, k) \quad \text { frekuensi kemunculan sebuah kata } w \text { dalam dokumen } k \text {, dimana } \\
& \text { dokumen } k \text { merajuk pada dokumen } d
\end{aligned}
$$

\subsection{Metode Naïve Bayes}

Metode Naïve Bayes atau Naïve Bayes Classifier (NBC) adalah salah satu metode yang digunakan untuk klasifikasi teks. NBC menggunakan teori probabilitas sebagai dasar teori. Dalam bukunya, Han, J. dan Kamber, M. menyatakan:

"Bayesian classifiers mempunyai tingkat kecepatan dan akurasi yang tinggi ketika diaplikasikan dalam database yang besar" (2001, hlm. 296).

Melalui pernyataan tersebut, maka metode $N B$ adalah metode yang dipergunakan untuk proses klasifikasi teks dalam penelitian ini. Terdapat 2 tahap pada proses klasifikasi teks. Tahap pertama adalah pelatihan terhadap himpunan artikel contoh (training example). Sedangkan tahap kedua adalah proses klasifikasi dokumen yang belum diketahui topiknya.

Theorema Bayes:

$$
P\left(C_{1} \mid X\right)=\frac{P\left(X \mid C_{1}\right) \times P\left(C_{1}\right)}{P(X)}
$$

Keterangan:

$P(\mathrm{Ci} \mid X)$

$X$

probabilitas kemunculan kelas $C i$ dengan kondisi $X$

$P(X)$ "konstan" untuk semua kelas sehingga hanya terbentuk $P(X \mid C i) \mathrm{x}$ $P(C i)$ yang perlu dimaksimumkan

$\mathrm{Ci} \quad$ : kelas yang tersedia $(C 1, C 2, \ldots C i)$

$P(C i) \quad$ : probabilitas kemunculan kelas $\mathrm{Ci}$

$P(X) \quad$ : probabilitas kemunculan kejadian $X$

$\mathrm{P}(\mathrm{X} \mid \mathrm{Ci} \quad) \quad$ : probabilitas kemunculan kejadian $X$ dengan kondisi $\mathrm{Ci}$

Keterangan:

$$
P\left(X \mid C_{1}\right)=\prod_{t=1}^{n} P\left(X_{t} \mid C_{1}\right)
$$

$X t$

$P(X t \mid C i)$
: nilai-nilai atribut dalam sample $X$

: probabilitas kejadian $\mathrm{Xt}$ dengan kondisi $\mathrm{Ci}$, dapat dihitung dari database training

\subsection{Metode Vector Space Model}

Metode Vector Space Model atau Term Vector Model adalah sebuah model aljabar untuk menggambarkan dokumen teks (beberapa objek) sebagai vektor dari identifier. Biasanya 
digunakan dalam penyaringan informasi (information filtering), penemuan informasi (information retrieval), indexing dan pemberian ranking yang saling relevan.

Proses dari perhitungan metode ini adalah indexing dokumen, pembobotan term dan perhitungan kesamaan. Proses indexing dokumen adalah proses melalui tahapan-tahapan dalam text mining. Proses selanjutnya adalah pembobotan term dengan menggunakan algoritma TFIDF. Proses yang terakhir adalah perhitungan kesamaan dengan pendekatan Cosine, yang dinyatakan dalam rumus (Frakes, W. B. \& Baeza, R., 1992, hlm. 366):

$$
\operatorname{Similarity}\left(d_{j}, q_{k}\right)=\frac{\sum_{i=1}^{n}\left(t_{i j} \times t_{i k}\right)}{\sqrt{\sum_{i=1}^{n} t d_{i j}^{2} \times \sum_{i=1}^{n} t_{i k}^{2}}}
$$

Keterangan:

$\begin{array}{ll}\text { Similarity }(d j, q k) & : \text { tingkat kesamaan suatu dokumen dengan query tertentu } \\ \text { tdij } & : \text { term ke-i dalam vektor untuk dokumen ke- } j \\ \text { tqik } & : \text { term ke-i dalam vektor untuk query ke-k } \\ n & : \text { jumlah term yang unik dalam data set }\end{array}$

\section{Hasil dan Pembahasan}

\subsection{Sistem Klasifikasi Naïve Bayes}

Terdapat 5 kategori, yaitu Health, Music, Politics, Sport dan Technology. Jumlah data training adalah 250 jurnal Proquest yang terdiri dari 50 jurnal untuk setiap kategorinya. Sedangkan data tester yang telah dipersiapkan adalah sebanyak 50 jurnal Proquest, masingmasing 10 jurnal pada setiap kategori.

Setiap jurnal training dan tester melewati proses text mining terlebih dahulu, yaitu text preprocessing, text transformation, feature selection dan pattern discovery. Setelah melewati proses text preprocessing, diperoleh jumlah training $=249$ jurnal, karena terdapat 1 jurnal berkategori Politics yang sama dalam database (id jurnal harus unik, tidak boleh kembar). Kemudian setelah melewati proses text transformation, terbentuk 3763 token yang unik.

Rancangan pengujian sistem klasifikasi akan difokuskan terhadap beberapa pilihan feature selection yang diambil, kemudian dilihat berdasarkan nilai precision yang diperoleh. Asumsi yang dipakai adalah jumlah vektor ideal adalah kurang dari $40 \%$ dari total token dan feature selection dikatakan baik apabila dapat menghasilkan nilai precision lebih dari $60 \%$. Beberapa pilihan feature selection yang akan dianalisis, yakni:

1. FS-1 : pengambilan keseluruhan token unik (diurutkan descending), kemudian diambil threshold sebanyak $n \%$.

2. FS-2 : pengambilan keseluruhan token unik dalam setiap jurnal (diurutkan descending), kemudian diambil threshold sebanyak $n \%$, serta digabungkan dan diunikkan kembali.

3. FS-3 : pengambilan keseluruhan token unik dalam setiap kategori (diurutkan descending), kemudian diambil threshold sebanyak $\mathrm{n} \%$, serta digabungkan dan diunikkan kembali.

4. FS-4 : pengambilan token-token yang pasti terkandung didalam setiap kategori.

Tabel 1 dan Gambar 3 menunjukkan hasil prediksi sistem klasifikasi dari semua percobaan yang dilakukan, yaitu dari setiap pemilihan feature selection beserta variasi threshold yang diambil. Sumbu $X$ merupakan pengujian yang dilakukan, sedangkan sumbu $Y$ adalah nilai precision yang dihasilkan. Terdapat tambahan berupa batas yang dipergunakan sebagai batas asumsi nilai precision yang baik, yaitu terletak pada precision $=60 \%$. 
Tabel 1 : Hasil Klasifikasi

\begin{tabular}{|c|c|c|c|c|c|c|c|c|c|c|}
\hline \multirow{3}{*}{ pengujian } & \multirow{3}{*}{ threshold } & \multirow{2}{*}{\multicolumn{2}{|c|}{ jumlah vektor }} & \multirow{3}{*}{$\begin{array}{c}\text { klasifikasi } \\
\text { salah }\end{array}$} & & & & & & \\
\hline & & & & & \multicolumn{5}{|c|}{ klasifikasi benar } & \multirow[b]{2}{*}{ precision } \\
\hline & & vektor & $\begin{array}{l}\text { vektor } \\
\text { ideal }\end{array}$ & & H & M & P & S & $T$ & \\
\hline \multirow{4}{*}{ FS - 1} & $10 \%$ & 376 & $10 \%$ & 38 & 1 & 1 & 4 & 4 & 2 & $24 \%$ \\
\hline & $20 \%$ & 752 & $20 \%$ & 43 & 0 & 0 & 1 & 5 & 1 & $14 \%$ \\
\hline & $30 \%$ & 1128 & $30 \%$ & 44 & 0 & 0 & 1 & 4 & 1 & $12 \%$ \\
\hline & $40 \%$ & 1505 & $40 \%$ & 47 & 0 & 0 & 1 & 1 & 1 & $6 \%$ \\
\hline \multirow{3}{*}{ FS - 2} & $10 \%$ & 701 & $18.63 \%$ & 45 & 0 & 0 & 1 & 2 & 2 & $10 \%$ \\
\hline & $20 \%$ & 1146 & $30.45 \%$ & 45 & 0 & 0 & 1 & 2 & 2 & $10 \%$ \\
\hline & $30 \%$ & 1585 & $42.12 \%$ & 46 & 1 & 0 & 0 & 2 & 1 & $8 \%$ \\
\hline \multirow{3}{*}{ FS -3} & $10 \%$ & 531 & $14.11 \%$ & 39 & 0 & 0 & 3 & 5 & 3 & $22 \%$ \\
\hline & $20 \%$ & 961 & $25.54 \%$ & 45 & 0 & 0 & 1 & 3 & 1 & $10 \%$ \\
\hline & $30 \%$ & 1366 & $36.30 \%$ & 45 & 0 & 0 & 1 & 2 & 2 & $10 \%$ \\
\hline \multirow{2}{*}{ FS - 4} & (Proquest) & 168 & $4.46 \%$ & 18 & 7 & 4 & 6 & 7 & 8 & $64 \%$ \\
\hline & $(\mathrm{CNN})$ & 204 & $5.42 \%$ & 35 & 8 & 4 & 2 & 0 & 1 & $30 \%$ \\
\hline
\end{tabular}

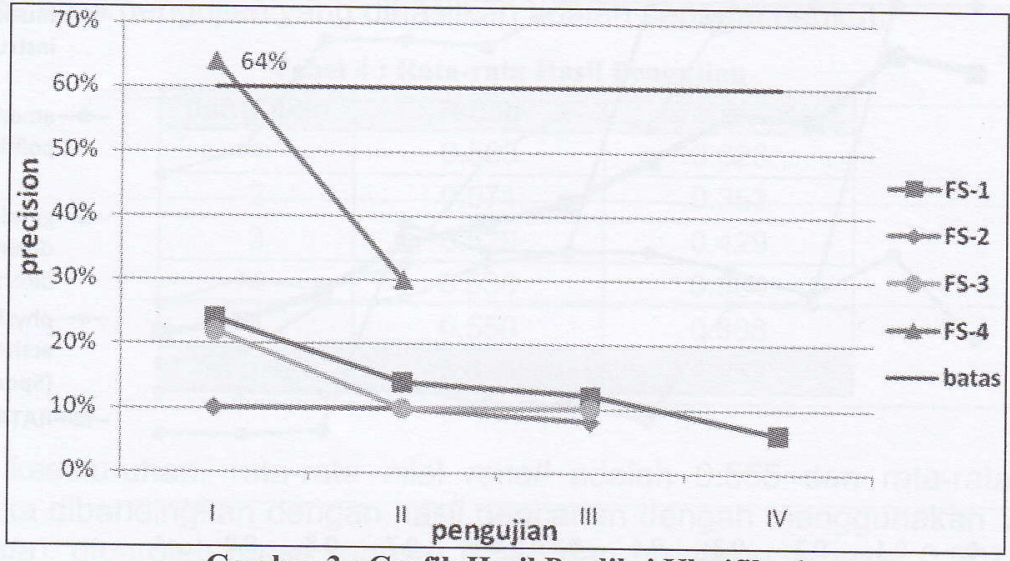

Gambar 3 : Grafik Hasil Prediksi Klasifikasi

Semakin besar tingkat threshold yang diambil dalam setiap feature selection (dilihat dari sumbu X), maka nilai precision akan semakin berkurang. Atau dengan kata lain, tingkat threshold berbanding terbalik dengan nilai precision-nya. Dalam grafik terlihat bahwa kecenderungan garis yang mengalami penurunan. Jika dilihat berdasarkan grafik secara langsung, maka dapat dinyatakan bahwa FS-4 dalam pengujian I (FS-4 dengan sumber Proquest) merupakan feature selection yang cukup baik, karena nilai precision yang diperoleh mencapai $64 \%$ (di atas batas asumsi).

\subsection{Sistem Pencarian dengan Vector Space Model pendekatan Cosine}

Data training yang digunakan serupa dengan data training pada pengujian sistem klasifikasi. Jumlah data training $=249$ jurnal dan token unik $=3763$ token. Sedangkan kata kunci tester diambil secara sembarang, dengan asumsi terdiri dari minimal 2 kata (lebih dari 1 kata). Analisis sistem pencarian dengan VSM dan pendekatan Cosine difokuskan pada nilai recall dan precision yang diperoleh.

Berikut adalah sampel pengujian dengan kata kunci "food and health", kemudian diperoleh jurnal relevan sebanyak $=63$ jurnal. Berikut hasil recall dan precision yang diperoleh: 
Tabel 2 : Hasil Pengujian dengan kata kunci "food and health"

\begin{tabular}{|c|c|c|c|c|}
\hline no & rank & id jurnal & recall & precision \\
\hline 1 & 1 & 1269225771 & 0.143 & 1.000 \\
\hline 2 & 2 & 1545625991 & 0.286 & 1.000 \\
\hline 3 & 3 & 1568059391 & 0.429 & 1.000 \\
\hline 4 & 8 & 1606130701 & 0.571 & 0.500 \\
\hline 5 & 9 & 1425140451 & 0.714 & 0.556 \\
\hline 6 & 42 & 1376156241 & 0.857 & 0.143 \\
\hline 7 & 52 & 1569188531 & 1.000 & 0.135 \\
\hline & \multicolumn{5}{|c|}{ rata - rata } & 0.571 & 0.619 \\
\hline
\end{tabular}

Berdasarkan beberapa pengujian yang dilakukan terhadap beberapa kata kunci, maka dapat digambarkan grafik interpolasi beserta rata-rata dari keseluruhan pengujian:

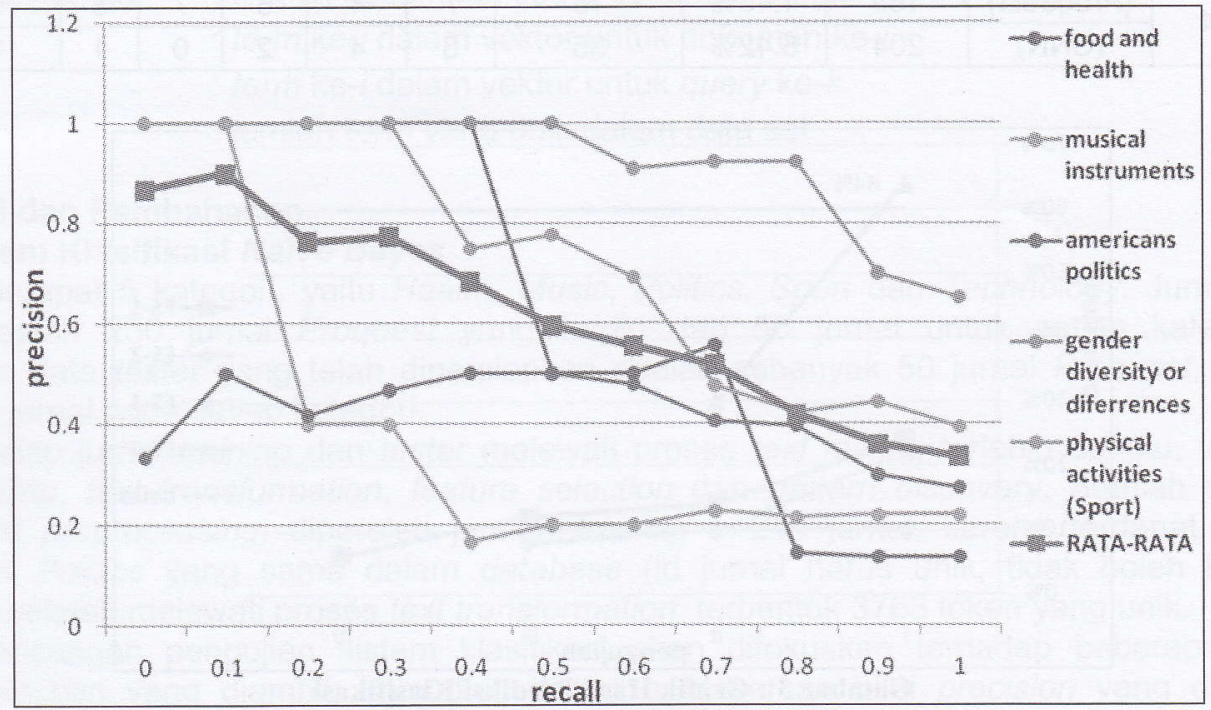

Gambar 4 : Gambar Interpolasi Recall / Precision

Rata-rata hasil pengujian yang dihasilkan adalah sebagai berikut:

Tabel 3 : Rata-rata Hasil Pengujian

\begin{tabular}{|c|c|c|}
\hline pengujian & recall & precision \\
\hline 1 & 0.571 & 0.619 \\
\hline 2 & 0.571 & 0.347 \\
\hline 3 & 0.528 & 0.410 \\
\hline 4 & 0.533 & 0.921 \\
\hline 5 & 0.538 & 0.740 \\
\hline rata-rata & 0.548 & 0.607 \\
\hline
\end{tabular}

\subsection{Sistem Klasifikasi dan Pencarian (gabungan)}

Pengujian yang dilakukan merupakan gabungan dari pengujian sebelumnya, yaitu hasil pengujian dari sistem pencarian dengan VSM ditambah dengan suatu label kategori yang diasumsikan sebagai hasil sistem klasifikasi dengan NB. Kemudian label kategori akan dipergunakan dalam pencarian detil terhadap metadata = kategori. Analisis sistem klasifikasi dan pencarian akan difokuskan pada nilai recall dan precision yang diperoleh. 


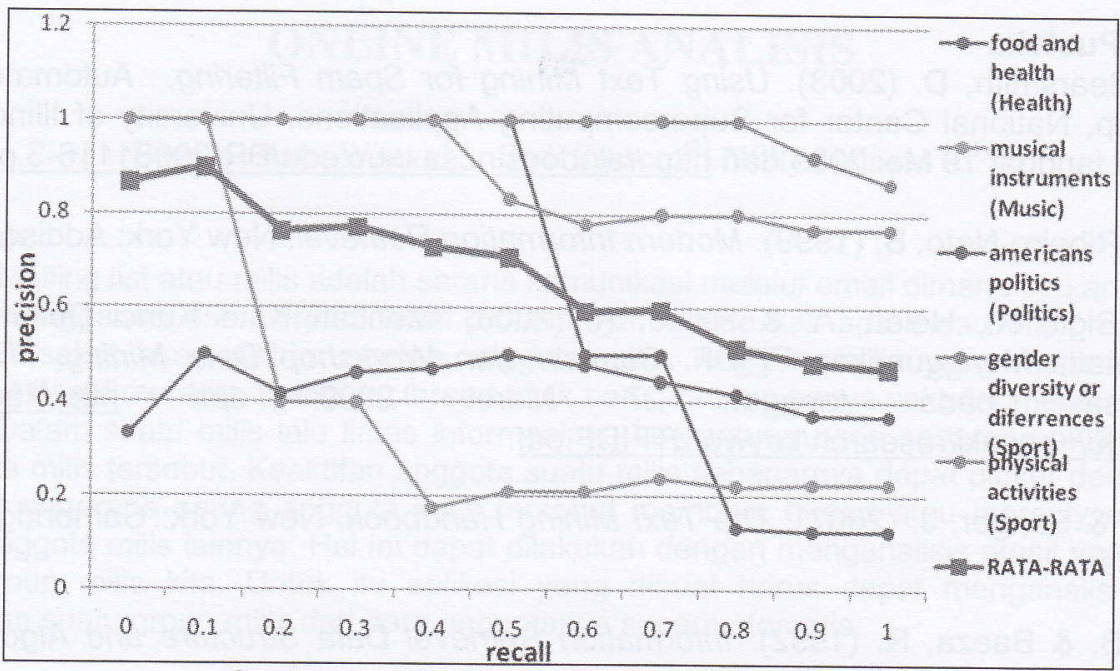

Gambar 5 : Gambar Interpolasi Recall / Precision

Rata-rata hasil pengujian yang dihasilkan adalah sebagai berikut:

Tabel 4 : Rata-rata Hasil Pengujian

\begin{tabular}{|c|c|c|}
\hline penguilan & recall & precision \\
\hline 1 & 0.583 & 0.626 \\
\hline 2 & 0.571 & 0.353 \\
\hline 3 & 0.529 & 0.429 \\
\hline 4 & 0.538 & 0.984 \\
\hline 5 & 0.550 & 0.868 \\
\hline rata-rata & $\mathbf{0 . 5 5 5}$ & 0.652 \\
\hline
\end{tabular}

Secara keseluruhan, rata-rata nilai recall adalah 0.555 dan rata-rata nilai precision adalah 0.657. Jika dibandingkan dengan hasil pencarian dengan menggunakan VSM saja (tanpa bantuan metadata), diperoleh recall sebesar 0.548 dan precision sebesar 0.607 , maka terdapat peningkatan nilai recall dan precision untuk sistem klasifikasi dan pencarian dengan bantuan metadata.

\section{Kesimpulan dan Saran}

Berdasarkan hasil analisis dan implementasi sistem, maka dapat disimpulkan:

- Sistem klasifikasi dengan metode Naïve Bayes dengan FS-4 menghasilkan precision sebesar $64 \%$.

- Sistem pencarian dengan metode Vector Space Model pendekatan Cosine menghasilkan recall sebesar $54.8 \%$ dan precision sebesar $60.7 \%$.

- Feature selection dengan bantuan pembobotan token menghasilkan precision kurang dari $60 \%$, jadi proses pembobotan token tidak mempengaruhi dalam sistem klasifikasi.

- Feature Selection dari sumber data pelatihan dan tester yang berbeda menghasilkan precision kurang dari $60 \%$, karena jangkauan topik pembicaraan yang cukup berbeda.

Penggunaan metadata (hasil klasifikasi) dalam proses pencarian dapat meningkatkan tingkat recall.

Saran untuk pengembangan dan perbaikan sistem ini adalah:

- Perlu adanya perbaikan struktur data untuk mempercepat proses text mining, karena semakin banyak jumlah data, semakin lama pula proses yang dibutuhkannya.

- Pengembangan sistem, yaitu sistem dapat menambahkan kategori baru. Pengembangan pencarian dengan kata kunci berupa frasa atau dengan penggunaan Boolean Operator (misal: OR, AND). 


\section{Daftar Pustaka}

Auvil, L. \& Searsmith, D. (2003). Using Text Mining for Spam Filtering. Automated Learning Group, National Center for Supercomputing Applications, University of Illinois. Diakses pada tanggal 19 Mei 2009 dari http://algdocs.ncsa.uiuc.edu/PR-20031116-3.ppt.

Baeza, R. \& Ribeiro-Neto, B. (1999). Modern Information Retrieval. New York: Addison Wesley.

Basuki, A., Sigit, R., Helen, A. \& Ridho, A. (2006). Mencari Kata Kunci Dokumen Secara Otomatis Menggunakan TFIDF. Seminar dan Workshop Data Mining, ITB Bandung. Diakses pada tanggal 27 Maret 2009 dari http://lecturer.eepisits.edu/ basuki/research/keywordTFIDF.pdf.

Feldman, R. \& Sanger, J. (2007). The Text Mining Handbook. New York: Cambridge University Press.

Frakes, W. B. \& Baeza, R. (1992). Information Retrieval Data Structure and Algorithms. New Jersey: Prentice-Hall.

Han, J. \& Kamber, M. (2001). Data Mining: Concepts and Techniques. San Francisco: Morgan Kaufmann.

Harlian, M. (2006). Text Mining. Diakses pada tanggal 27 Maret 2009 dari http://lecturer.eepisits.edu/ iwanarif/kuliah/dm/6Text\%20Mining.pdf.

Intan, R. \& Defeng, A. (2006). HARD: Subject-Based Search Engine Menggunakan TF-IDF dan Jaccard's Coefficient. Diakses pada tanggal 24 Mei 2009 dari http://puslit.petra.ac.id/journals/pdf.php?PublishedID=IND06080106.

Wibisono, Y. (2005). Klasifikasi Berita Berbahasa Indonesia menggunakan Naïve Bayes Classifier. Seminar Nasional Matematika. Diakses pada tanggal 27 Maret 2009 dari http://fpmipa.upi.edu/staff/yudi/yudi 0805.pdf. 